\section{Matjaz Celarc}

University of Ljubljana (Slovenia)

Matjaz.Celarc@teof.uni-lj.si

ORCID 0000-0001-9586-6955

DOI: http://dx.doi.org/10.12775/BPTh.2021.006
Biblica

et

Patristica

Thoruniensia

14 (2021) 2: 129-144

ISSN (print) 1689-5150

ISSN (online) 2450-7059

\title{
Narrative summaries in Acts of the Apostles. Analytical Instruments
}

\begin{abstract}
This article presents an explanation of interpretational tools used for reading the summary narrative accounts in the Acts of the Apostles. This reading combines a Point of View Analysis with Intertextual Reading, hearing the echoes of and allusions to the Isaianic prophecies in the summary descriptions.
\end{abstract}

Keywords: point of view analysis; intertextual reading; Isaianic New Exodus; nascent community.

\section{Introduction}

Questions surrounding who or what is the Church have accompanied me, since my theological studies. Reading the narrative summaries in the Acts of the Apostles which describe the life of the first church community: (1) breaking bread at the common table, (2) sharing belongings, and (3) looking after the sick, inspired me then - as it still does now-to desire and to pursue this realized ideal. The community growing, despite the external and internal conflicts, shows that this life is not the fruit of a human decision or human efforts, but the fruit of God's work and blessing. In a series consisting of four articles, I would like to begin with this first one, considering the methodological instruments Point of View Analysis and Intertextuality and, subsequently, some results of a careful reading of these three specific texts.

\section{Summary as a specific narrative form}

The narrative summary or summary account is a specific narrative form. Whereas the narrative episodes show the narrative development in a sequence 
of aorists, the summaries tell about the events that took place over a longer time span or continued in the past through a sequence of verbs in the imperfect tense. (Niccacci 1992, 87-89) The summary is thus defined as an unfocused, generalized description that functions as connective tissue between the different stages of the narrative. For this reason, scholars tend to disregard or underestimate the narrative value of the summaries. However, the summaries functioning as narrative pauses are important for at least four reasons:

(1) First, they permit the reader to reflect upon the "mood of the narrative," (Chatman 1978, 141) and the background "narrative setting" (Marguerat and Bourquin 2001, 83-90) that encompasses the narrative plot.

(2) Second, they permit the reader to partake in the narrator's omniscience, his point of view and focalization. As a corollary, the reader better understands both the narrative plot and the characters.

(3) Third, the summaries describe the habitual actions of the generalised group character. However, through the general traits the identity of a group emerges, which is meaningful for understanding the surrounding narrative.

(4) Fourth, the summaries and their narrative echoes (i.e., shorter summary statements within the narrative) have an ana-/proleptic function and guide the reader through the story.

Thus, the summaries permit the narrator to guide the reader through the story, to form his sympathy towards some narrative characters or actions, whereas downplaying others.

Due to this specific narrative nature of the summary (i.e., considering the form and content) two methodological tools best suit an analytical reading: (1) point of view analysis; and (2) intertextuality.

\section{Point of View Analysis}

Based on these observations it seems worthwhile to reflect on Point of View Analysis (PVA). Narratology has developed a form of PVA that carefully observes movements from the background to the foreground, from the narrator's telling or basic description to his showing the actions and words of the characters. (Marguerat 2010, 331-354) PVA acquaints the reader with the narrator's manner of writing and his ideological concerns and thus helps the reader 
to grasp the meaning of the narrative. For the purpose of understanding this method, let me briefly identify the main proponents of PVA.

PVA was first described by Boris Uspensky (1983, 1-6), who related the creation of texts to the problem of the composition of a work in the visual arts. He limits his analysis to literary compositions, delineating five planes: ideological, phraseological, spatial, temporal, and psychological. Uspensky gives special attention to the ideological plane on which all the other planes converge. $\mathrm{He}$ defines this plane as "the system of ideas that shape the work," i.e., "the deep compositional structure, as opposed to the surface compositional structure which may be traced on the psychological, spatio-temporal, or phraseological levels." $(1983,8)$. Thus, the composition reflects the artistry of the narrator who connects different planes of meaning in order to guide the reader to the correct understanding of the narrative.

While noting the contribution of scholars such as Gérard Genette (1980), who spoke of three types of focalization, and Alain Rabatel (2004), who introduced a three-fold categorization of the point of view-both important for the diachronic development of PVA-here I focus on the recent contribution of Israeli linguist Shlomith Rimmon-Kenan (2002, 79-84). Rimmon-Kenan speaks about facets of focalization, identifying a: (1) perceptual facet, which includes the spatial and temporal dimensions; (2) psychological facet, which comprises the cognitive and emotional dimensions; and an (3) ideological facet, which consists of the general system of viewing the world conceptually. Her classification signifies a return to the terminology proposed by Uspensky, yet without disregard of the distinctive focalization of either narrator or character. Rimmon-Kenan $(2002,87)$ thus concludes:

If the focalizer is a character, the argument goes, then his acts of perception are part of the story. If he is the narrator, focalization is just one of many rhetorical strategies at his disposal.

Although the overall language of the text is that of the narrator, Rimmon-Kenan $(2002,85)$ justly points out, that the "focalization can 'colour' it in a way which makes it appear as a transposition of the perceptions of a separate agent." However, "the ideology of the narrator-focalizer is usually taken as authoritative, and all other ideologies in the text are evaluated from this 'higher' position." $(2002,84)$ With regard to examining the summaries, the classification proposed by Rimmon-Kenan seems particularly appropriate because it brings 
together the elements of framing in the ideological facet which represents a trace or a voice that the narrator left behind. The narrator's focalization is decisive and is a measure of all other ideologies in the text. However, another hermeneutical question must be addressed. PVA, by focusing on the narrative frame, helps to uncover Luke's concerns and ideals in his depiction of the community.

\section{Intertextuality}

The study of Luke's use of the text of Israel's tradition is certainly not completely new. (Moyise 2000, 14-41) Source and Redaction Criticism and, in addition, the study of the history of religions have examined the similarities or emendations of the literary pattern and motifs. However, an intertextual approach emphasizes the composite texture of the text. The text is perceived as "an intersection of texts" as Timothy Beal $(2000,128)$ claims, and the intertextual reading disentangles the "traces of anterior texts in later texts" as Willem Vorster $(1989,15)$ defines it. Although this hermeneutical approach does not resolve the question concerning the relationship between the author, the text and the reader, as its emphasis lies on the dialogue between the text and the reader, it best suits our purpose to understand the OT allusions within the narrative frame of the summaries.

\subsection{Intertextuality as a hermeneutical problem}

For a better understanding of this approach, a brief overview on the authors who adopt this methodology seems appropriate. Julia Kristeva (1969), a Bulgarian-French linguist, was the first to speak about intertextuality. She forged this notion within a discussion concerning the logic of the language, i.e., poetic meaning as having a dynamic range. Following the Russian linguist Mikhail Bakhtine in his dynamic use of the language, Kristeva $(1969,83)$ points out that

the 'literary word' is not a point (fixed meaning) but rather crossing of textual surfaces, a dialogue of several writings: of the writer, of addressee (or of a person), of the cultural context, actual or antecedent.

For Kristeva, the text is not stable, and thus the interpretation of the text is fluid and can be sought within the continuous dialogue between different 
contexts, or to express it in words of Roland Barthes $(1973,59)$, it is defined as a "circular memory." It is true that there is the battleground between readeroriented and author-oriented makes this approach "internally dissonant," as Geoffrey Miller $(2011,304)$ concludes; nevertheless, the implied-author leaves some traces that give the reader some hints about what the author's world-view and intention might be. A trace of his plan is emended in the conventions or type of writing, as John Austin (1962, 14-15), followed by John Searle, claims for the speech-act theory (SAT).

While Roland Barthes $(1973,59)$ defends the "infiniteness" of the intertexts, Michael Riffaterre $(1984,142)$ reformulates the initial subjective definition of intertextuality as "an operation of the reader's mind" when he observes how the mimetic text refers to reality through the systems of signs that are ready-made textual units. Hence, he concludes that only the "presence of lexical connectors makes the perception of intertextual references compulsory and inescapable." (1984, 159)

Based on the reader-oriented perspective, John Goldingay $(1993,6-7)$ observes how the intended ambiguities of the text are resolved by the reader's activity of "filling the gaps," as the reader "reads into the text, giving the meaning to the texts" from/within his hermeneutical world. However, this hermeneutical impasse, resulting from the impossibility of total understanding "does not negate the worth of attempting whatever degree of understanding," especially when one observes a "tacit agreement on grammar [and] overlap between interpretations," as Goldingay $(1993,8)$ underlines.

Scholars as Stefan Alkier $(2013,295)$ have tried to classify the intertextuality into two groups, thus:

1. Limited intertextuality: This position considers only those textual relations which are written into a given text, or at least can be postulated on the basis of the signs collected in the text. These relations are to be investigated with methodological control; that is, interpreters consider the various ways of quoting, marking, and addressing references. The consideration of other potential texts in the text under investigation should be thoroughly differentiated and made hermeneutically fruitful. 2. Unlimited intertextuality: This position holds that a given text stands in a relationship with the entire universe of texts, including those which were produced after it and even those which are still to be produced. A single text is not an autonomous entity, but rather is integrated into an endless, unpredictable, and therefore indomitable multitude of interwoven connections with other texts, which are constantly shifting. This makes its meaning uncontrollable. 
The solution in tracing a path to overcome radical unlimited subjectivity is delineated in two steps. First, by revisiting the hermeneutical problem of the relations between the reader, text and author. Second, by considering some methodological proposals in order to arrive at a set of criteria for intertextual reading.

\subsection{Relation between of the reader, text and author}

Although the intertextual theories are critical of diachronic approaches, it seems clear that the intertextual approach cannot circumvent the author, as Ellen van Wolde concludes:

A writer should neither be regarded as a completely autonomous and conscious authority, nor as a reproducer of previous texts, but as a reader, 'digester' and rearranger of text and experiences.

Thus, while the writer on the one hand maintains "a living dialogue" between the texts through his writing as "a processing of other (con)texts and also a reply to other (con)texts," $(1989,46)$ the texts on the other hand reveal to the reader something about the author and the meaning of the text. (Vorster 1989, 26) Speaking of the relation between the texts, three stages can be differentiated: (1) quotation, (2) allusion and (3) echo. A quotation is an intentional, explicit, verbatim or near verbatim citation of a former text, usually accompanied by a quotation formula. The distinction between allusion and echo remains vague. Whereas John Hollander (1981, 65-66) makes a distinction regarding the author's conscious intention and Richard Hays $(1989,29)$ concerning the volume of the echo, Gary Manning $(2004,13)$ tries to merge the positions in his claim that "direct allusions are intended to draw the reader's attention to source text, whereas echoes are part of the author's pattern of writing."

The summaries in Acts do not contain explicit references to Isaiah or the OT text and the volume (i.e., extent) of correlation is weak. Therefore, these can be understood as oscillating between allusion and echo.

\subsection{Criteria of intertextual reading}

The intertextual reading faces a great subjective challenge, because it is not "a strictly scientific matter lending itself to conclusive proof," but rather, in 
Hays' words $(2005,30)$, it is "an art practiced by skilled interpreters within a reading community," thus it requires some criteria.

While Hollander $(1981,65)$ affirms that the reader must uncover the "cave of resonant signification" in order to understand the allusion, Ziva Ben-Porat $(1978,110-111)$ seeks to discern "allusion markers" within the text so that the relationship between the texts is unravelled in four gradual steps:

(1) identification of a marker;

(2) identification of the evoked text;

(3) modification of the referent by the evoked text;

(4) activation of the evoked text as a whole.

Richard Hays (1989), following Hollander's insights, interprets intertextuality as a wide-ranging interplay between texts that invites the reader back to the precursor. Thus, Hays $(1989,29-32)$ introduces seven criteria of intertextual connection that demand close observation:
(1) availability;
(2) volume;
(3) recurrence;
(4) thematic coherence;
(5) historical plausibility;
(6) history of interpretation;
(7) satisfaction.

\section{Forming an intertextual net}

Luke subtly introduced his allusions to the OT, knitting them into the narrative or letting them be pronounced by characters, as Richard Hays $(2016,192)$ observes:

Luke sees the Old Testament not merely as a collection about a future Messiah but rather as a book of self-involving promises made by God to the people of Israel.

In addition, the Isaianic New Exodus provides important prophetic material that Luke adopted for his two-volume composition. In order to elaborate a criteriological net, i.e., intertextual channel or cave of resonance, I give a brief overview of Hays' criteria. 


\subsection{Availability}

(1) Concerning the criterion of availability: Luke referred to the text of Isaiah, as a broadly recognized Scripture in the time of Jesus' followers. This is confirmed both by the number and recurrence of the citations of Isaiah in Lk-Acts (as in the N-A 27th edition) as well as the contemporary use of the prophet by the community of Qumran.

\subsection{Volume}

(2) Concerning the criterion of volume: For Hays $(2005,35)$, volume means, "how insistently the echo presses itself upon the reader." He enumerates three additional factors: (a) the degree of verbatim repetition; (b) the distinctiveness, prominence or popular familiarity of the precursor text; and (c) rhetorical stress of the phrase(s) in question. In other words, for Hays the volume of echo grows if there is similarity in context between two texts, and if uses of extended length and variety are made of the precursor text.

Whereas Hays' criterion seems vague, Manning (2004, 6-9) elaborates a more precise criteriology that permits a better understanding of what constitutes volume. Manning, by using the figurative image of an "hourglass," sheds light on how the meaning flows through the allusion from the source document to the alluding document. He enumerates six criteria: (1) the number of words, (2) the similarity in their use, (3) how they compare against other possible sources, (4) the presence of structural parallels, (5) repeated allusion to the same or nearby passages, (6) resonance between the original context and the context of the allusion. As the summaries (the interpretive device in the background of the narrative) do not contain explicit references to Isaiah or the OT text, the volume (i.e., extent) of correlation is weak, oscillating between allusion (direct and conscious reference) and echo (unintentional hint). Thus, the accumulation and continuous reference to different passages and Isaianic contexts confirms the claim of a real intertextual correlation between the summaries in Acts (and their contexts) and Isaiah, albeit not exclusive, since a lexical analysis indicates other possible correlations. 


\subsection{Recurrence}

Hays' criterion of recurrence (i.e., multiple attestations to a given text) is demonstrated by observing Luke's specific use of Isaiah, as indicated both (1) in the list of N-A $27^{\text {th }}$ as well as (2) in some scholarly contributions.

(1) A brief overview of the list in N-A $27^{\text {th }}$, shows that Isaiah is alluded more than 100 times. Moreover, the cluster of Isaianic references can be narrowed down to Isa 40-65. Hays (2016, 216-217) points out some of Luke's specific editorial moves. First, by extending the quotation of Isa 40:3-5 LXX in Lk 3:3-6 in order to create a climax in "all flesh shall see the salvation of God." Second, the "salvation" prepared in the presence of all the people (Isa 40) in Lk 2:30-32; 3:6. Third, the "light for revelation of the Gentiles" (Isa 42:6; 49:6) in Lk 2:30-32; Acts 13:47. In addition, there is a reference to Isa 6:9-10 that Luke adopts, following the synoptics, in the context of the parable of the sower ( $\operatorname{Lk} 8: 10)$, but he quotes it again at the end of Acts, as Paul's prophetic evaluation of the mission to the Jews (Acts 28:26). The fact, that all these quotations have both a compositional and an interpretative function in the narrative Luke-Acts, hints at the importance of Isaiah for Luke's work.

(2) Some scholarly contributions: Different scholars point to this same fact, namely of Luke's specific use of Isaiah, and demonstrate a broader thematic and lexical correspondences with Isaiah's adaptation of Israel's constitutive story of Exodus, i.e., to the Isaianic New Exodus. Jindřich Mánek (1957) represents a "pace setter" voicing a common expression of this concern. He proposes an intertextual relation between Luke and Isaiah. Dealing with the scene of the transfiguration, he endeavours to explain the meaning of Jesus' exodus in Jerusalem (Lk 9:31). For Mánek, the term exodus can mean leaving the sepulchre, the realm of death, but definitely not Jesus' end, his death, his crucifixion. Such an explanation seems to be not only in accord with the original meaning of the word exodus, but also with Luke's Christology centred on Christ's resurrection. Using the word exodus, Luke means "going out" rather than "end" or "death." It is a theological keyword relating to the prophetic typology (cf. Acts 3:22; 7:37; Deut 18:15), as Mánek claims it. (1957, 12-19)

The monograph of David Pao Acts and the Isaianic New Exodus (2000), which focuses on this restoration pattern, is enlightening. Pao endeavours to explain Luke's hermeneutical framing in reformulating the foundational story of Exodus reshaped in the Isaianic corpus. The goals of Pao's work are threefold. First, to address the significance of the quotation from Isaiah at the beginning of Jesus' ministry. Second, to prove there is an Isaianic influence on the Lukan narrative framework. Third, to examine the Isaianic themes that govern the narrative: (1) the restoration of the peo- 
ple; (2) the word of God; (3) anti-idolatry polemic and (4) the status of the Gentiles. (2000, 18-19) Moreover, five programmatic statements (Lk 4:16-30; 24:44-49; Acts $1: 8 ; 13: 46-47 ; 28: 25-28$ ), incorporating the themes of the rejection (cf. Isa 6:9-10; Acts 28:25-28) and the inclusion of the Gentiles (cf. Isa 49:6; Acts 13:46-47) emphasize the continuity and discontinuity of the Christian community, i.e., that the Gentiles can also be included in the redefined people of God. (2000, 109-110)

Most recently, Holly Beers (2015) presents her analysis of the Lukan narrative based upon typological and intertextual hermeneutic assumptions in order to paint Jesus and his disciples as the Isaianic servants. Beers $(2015,30)$ is convinced that the use of Isaiah in Luke-Acts may be explained through SAT, claiming:

Luke's illocutionary act in using Isaianic servant material is to portray Jesus and the disciples as embodying the servant vocation [...]. The assumed perlocutionary effect is first for the implied reader/hearer to be persuaded of this identification and second, to recognize her place as a follower of Jesus."

\subsection{Thematic coherence}

Concerning thematic coherence, on the pattern of restoration of the people designated as the Isaianic New Exodus (NE). This should provide the tool to discern the verbal-thematic elements of this intertextual interplay, and ultimately to confirm the initial proposal that Luke portrays the Restoration of the People of God as the fulfilment of Isaianic hopes.

First, a concise thematic presentation of Isaiah could help to reinforce the "cave of resonant significance". While John Goldingay $(2014,61-87)$ enumerates three criteria: (1) the proclamation of the sovereignty of God, (2) the role of the servant, and (3) the placement of the nations and Pao (2000, 18-19) displays four: (1) the true people of God, (2) the Word of God, (3) God's supremacy, (4) the Gentiles; Rebecca Denova $(1997,25-26)$ formulates five themes of the restoration: $(1)$ the remnant $(10: 22-23 ; 14: 1-2)$; (2) the release of the captives $(49: 22-26 ; 60: 1-17)$; (3) the inclusion of the nations that would worship the God of Israel (49:7; 56:5); (4) the condemnation of the unrepentant (66:24); (5) the restoration of Zion (2:2-4; 62:1-12).

Based on the concise presentations of NE as presented above, I propose the following set of five thematic criteria that are present, at least to some extent, in the opening chapter (cf. Isa 40) and are developed and found throughout the narrative of Isaiah. 
(1) God's sovereignty;

(2) The people of God;

(3) The release of captives;

(4) The response to God;

(5) The universal call to salvation.

(1) The first point exhibits a theological concern and merges awareness of the elements of God's creative power and sovereignty with the experience of salvation over the forces of evil and idols (cf. 35:3-9; 43:19-21; 44:3-5; 51:9-13; 55:1-3). In the inaugural chapter telling of God's intervention, one point is made clear. The restoration program discloses God's purpose for his people through the agency of his word, thus:

40:1 Comfort, O comfort my people [...]

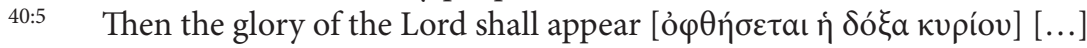

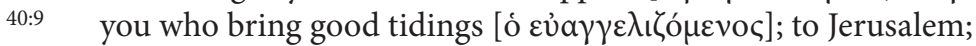

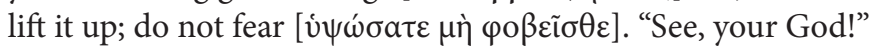

(2) The second point, an ecclesiological concern is based on divine intervention for the purpose of unifying the people of God by ingathering the exiles and the diaspora (cf. Isa 41:8-10; 43:5-7; 45:20-23; 49:22-23). In the inauguration speech, the figure of the shepherd evokes the image of the gathered flock. This theme, however, remains crucial for the later narrative account.

40:11 He will tend his flock as a shepherd,

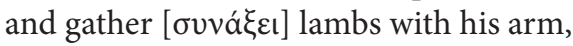
and comfort those that are with young.

(3) The third point, a socio-anthropological dimension of righteousness is theologically based (Isa 41:2) on the remission of sins (cf. Isa 43:25; 44:22). The establishment of social justice is the mission of the Servant (42:6) and a prerequisite for the unity of the people. The true worship of God requires that social justice is exercised through the hospitality of their homes (cf. 56:1-2; 58:6-12; 60:17-18; 65:13-16), whereas the harsh critique, in this regard, is addressed against the wicked rulers of the people (cf. Isa 28:14-15; 56:11) who are working for their personal gain.

40:3 Prepare ye the way of the Lord, make straight the paths of our God.

58:6 [...] loose every burden of injustice [...].

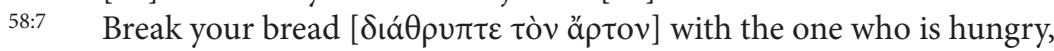

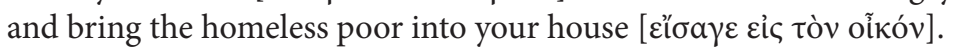


(4) The fourth point represents a natural reaction to the experience of salvation in an outburst of joy and exultation (cf. Isa 35; 61).

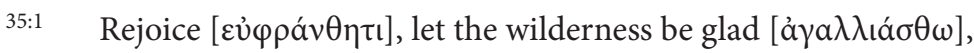

35:10 those gathered together because of the Lord shall return

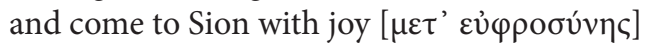

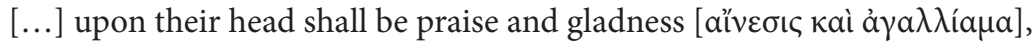

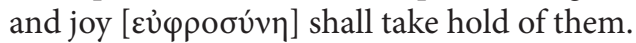

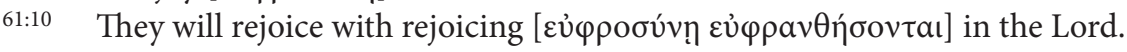

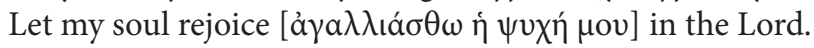

The experience of salvation and joy is expressed in prayer. Although the prayer is primarily spatially related with the restoration of Zion/Jerusalem and the temple (cf. 51:17-52:2; 54:11-17; 56:6-7), God, however, remains sovereign and looks toward the humble $(57: 15 ; 66: 1-2)$. True worship is not performed by lips, guided by human precepts (29:13), but rather demands a coherence and integrity of life (58:6).

56:5 I will give them an everlasting name, $[\ldots]$

56:7 I will bring them into my holy mountain,

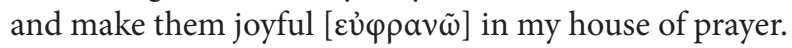

(5) Concerning the fifth issue of the universal repercussion, the restoration is not circumscribed solely to Israel. The ecclesiological dimension has universal scope. Israel's election has the capacity to extend the experience of salvation to the entire world (cf. $42: 6 ; 45: 23 ; 49: 6 ; 55: 5 ; 56: 6-8 ; 60: 10-16$ ), as predicted at the beginning of Isaiah 40 .
40:5 all flesh shall see the salvation of God [ơ $\theta \varepsilon$ cõ].
$42: 6$
I have given you as a covenant to a race, as a light to nations

These five criteria will be employed as a tool in discerning the intertextual allusion of NE in Acts. In a concise way, I foreshadow here the basic correlations that the exegetical analysis will try to evaluate.

(1) God's sovereignty is shown in the formation and growth of the community:

2:47 "The Lord added to their community those destined to be saved"

(2) Restoration of the people of God:

4:32 "The community of believers was of one heart and mind" 
(3) Social dimension:

4:34 "There was no needy person among them"

(4) Response to salvation with prayer and joy:

2:46 "They ate their meals [in homes] with exultation and sincerity of heart"

(5) Universal call to salvation:

5:16 "[...] people from the towns in the vicinity of Jerusalem also gathered"

As a consequence, the allusions that evoke the Isaianic NE point to the continuity with OT tradition and display Luke's main ideological concern in terms of the restoration of the people of God.

\subsection{Historical plausibility}

Concerning historical plausibility, the external literary evidence (e.g. some Qumran texts) points to the fact that the Jewish sectarian groups used the Isaianic text for the portrayal of their identity.

In the document Rule of the Community (1QS), the community, portrayed as an eschatological assembly 1QS 9:14.18.19 (cf. 1QSa 1:1), is defined as: (a) the chosen ones, (b) those separated to foster sanctity of life, and (c) life in unity. For each of these points some Isaianic allusions are adopted. (Schofield 2009, 69-130)

(a) Concerning the characterisation of the community as the chosen ones, the members represent the house of holiness for Israel and the assembly of Supreme Holiness for Aaron, that atones for the whole country (1QS 8:5-10). Their self-understanding is formulated in Isaianic terms, as an everlasting plantation (1QS 8:5; 11:8 [למטעת עולם]; Isa 61:3, cf. 11:1; 60:21; 27:2) and as the precious corner stone (1QS 8:7 [פנת יקרב ילמר], Isa 28:16). (Pouilly 1976, 86-87; Hannah 2005, 12-13)

(b) Concerning their separation from the world has two goals. First, to prepare the way for the Lord (1QS 9:19 [פנות לדבר הדרך]; Isa 40:3). (Fitzmyer 1961, 317-318) Second, separating themselves from the ungodly people (1QS 9:20 [הבדל מכול איש]), permits the community to form Israel's holy remnant (cf. also Isa 10:20-21) or House of Holiness (1QS 9:6).

(c) Concerning the life of the community, i.e., the "men of the community" (1QS 5:1), it is determined by their unity (1QS 5:3-4) and defined as an "eternal covenant" (1QS 5:5-6 [ברית עולם]; Isa 55:3; 61:8). (Pouilly 1976, 96-102) As a corollary, blessing in terms of healing, peace, numerous offspring and eter- 
nal joy is promised (1QS 4:7-8). In this regard, the text echoes different parts of Isaiah (cf. Isa 48:17-19; 61:10; 62:10).

\subsection{History of interpretation}

Concerning the history of interpretation, I have already pointed out some recent authors finding additional communitarian interpretations of Isaiah in Qumran.

\subsection{Satisfaction}

Concerning satisfaction, I have already pointed out the narrative function of the summaries, i.e., the interpretative voice of the narrator in the background of the narrative, that has as its consequence that only verbal and thematic allusions and echoes emerge. The results are present, albeit limited. If the reading of the Isaianic echoes in Luke, as Richard Hays $(2010,68)$ claims: "goes far beyond anything that can be ascribed with any degree of confidence to Luke's authorial intention," thus, it requires "an integrative act of discernment," as Hays (2005, 44) also observes. Thus, the results come in a cumulative way, finding their confirmation in Luke's specific use of Isaiah not only in the summary accounts in Acts of the apostles but also in the surrounding context.

\section{Synthesis}

With this present article I have suggested some limits and offered two useful tools (PVA and Intertextuality) that consider the nature and the content of the summaries in Acts, whereas the subsequent article on the first summary account in Acts of the apostles $(2,42-47)$ will present some fruits of the adoption of these reading tools.

\section{Bibliography}

Alkier, Stefan. 2013. "Reading the Canon Intertextually. The Decentralization of Meaning." In Between Text and Text. The Hermeneutics of Intertextuality in Ancient Cultures and Their Afterlife in Medieval and Modern Times, edited by Michaela Bauks, 288-302. Göttingen: Vandenhoeck \& Ruprecht. 
Austin, John Langshaw. 1962. How to Do Things With Words. Oxford: Oxford University Press.

Barthes, Roland. 1973. Le plaisir du texte. Paris: Seuil.

Beal, Timothy K. 2000. "Intertextuality." In Handbook of Postmodern Biblical Interpretation, edited by Andrew Keith Malcom Adam, 128-130. St. Louis MO: Chalice Press.

Beers, Holly. 2015. The Followers of Jesus as the "Servant." Luke's Model from Isaiah for the Disciples in Luke-Acts. Vol. 535, Library of New Testament Studies. London: Bloomsbury Publishing.

Ben-Porat, Ziva. 1978. “The Poetics of Literary Allusion." A Journal for Descriptive Poetics and Theory of Literature 1:105-128.

Chatman, Seymour. 1978. Story and Discourse. Narrative Structure in Fiction and Film. Ithaca NY: Cornell University Press.

Denova, Rebecca I. 1997. The Things Accomplished Among Us. Prophetic Tradition in the Structural Pattern of Luke-Acts. Vol. 141, Journal for the Study of the New Testament Supplement. Sheffield: Academic Press.

Fitzmyer, Joseph A. 1961. “The Use of Explicit Old Testament Quotations in Qumran Literature and in the New Testament." New Testament Studies 7:297-333.

Genette, Gérard. 1980. Narrative Discourse. An Essay in Method. Translated by Jonathan Culler and E. Lewin Jane. Ithaca NY: Cornell University Press.

Genette, Gérard. 1982. Palimpsestes. La littérature au second degré. Vol. 257, Points. Paris: Seuil.

Goldingay, John E. 1993. "How Far Do Readers Make Sense? Interpreting Biblical Narrative." Themelios 18.2:5-10.

Goldingay, John E. 2014. The Theology of the Book of Isaiah. Downers Grove IL: InterVarsity Press.

Hannah, Darrell D. 2005. "Isaiah within Judaism of the Second Temple Period." In Isaiah in the New Testament, edited by Steve Moyise and Maarten J. J. Menken, 7-33. London: T \& T Clark.

Hays, Richard B. 1989. Echoes of Scripture in the Letters of Paul. New Haven, CT: Yale University Press.

Hays, Richard B. 2005. The Conversion of the Imagination. Paul as Interpreter of Israel's Scripture. Grand Rapids MI: Eerdmans.

Hays, Richard B. 2010. "Intertextuality, Narrative, and the Problem of Unity of the Biblical Canon." In Kanon und Intertextualität. Mit einer Beigabe von J. Herzer zur Einführung in das Werk von Richard B. Hays, edited by Stefan Alkier and Richard B. Hays, 53-70. Frankfurt am Main: Lembeck

Hays, Richard B. 2016. Echoes of Scripture in the Gospels. Waco (TX): Baylor University Press.

Hollander, John. 1981. The Figure of Echo. A Mode of Allusion in Milton and After. Berkeley: University of California.

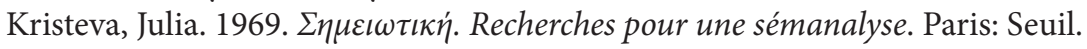


Mallen, Peter. 2007. The Reading and Transformation of Isaiah in Luke-Acts. Vol. 367, Library of New Testament Studies. London: T \& T Clark.

Mánek, Jindřich. 1957. “The New Exodus in the Books of Luke." Novum Testamentum 2:8-23.

Manning, Gary T., Jr. 2004. Echoes of a Prophet. The Use of Ezekiel in the Gospel of John and in Literature of the Second Temple Period. Vol. 270, Journal for the Study of the New Testament Supplement. London: T \& T Clark.

Marguerat, Daniel. 2010. "Il »Punto di vista« nella narrazione biblica." RivB LVIII:331-354.

Marguerat, Daniel, and Yvan Bourquin. 2001. Per leggere i racconti biblici. La Bibbia si racconta. Iniziazione all'analisi narrativa. Roma: Borla.

Miller, Geoffrey D. 2011. "Intertextuality in Old Testament Research." Currents in Biblical Research 9.3:283-309.

Moyise, Steve. 2000. "Intertextuality and the Study of the Old Testament in the New Testament." In The Old Testament in the New Testament. Essays in Honour of J.L. North, edited by J. L. North and Steve Moyise, 14-41. Sheffield: Academic Press.

Niccacci, Alviero. 1992. "Dall'aoristo all'imperfetto, o dal primo piano allo sfondo. Un paragone tra sintassi greca e sintassi ebraica." Liber annuus 42:85-108.

Pao, David W. 2000. Acts and the Isaianic New Exodus. Tübingen: Mohr Siebeck.

Pouilly, Jean Ocso. 1976. La Règle de la Communauté de Qumrân. Son évolution Littéraire. Vol. 17, Cahiers de la Revue biblique. Paris: J. Gabalda.

Rabatel, Alain. 2004. Argumenter en racontant. (Re)lire et (ré)écrire les textes littéraires, Savoirs en Pratique. Paris: De Boeck.

Riffaterre, Michael. 1984. "Intertextual Representation. On Mimesis as Interpretive Discourse." Critical Inquiry 11 (1):141-162. doi: 10.2307/1343294.

Rimmon-Kenan, Shlomith. 2002. Narrative Fiction. Contemporary Poetics. 2 ed. London: Methuen.

Schofield, Alison. 2009. From Qumran to the Yahad. A New Paradigm of Textual Development for The Community Rule. Vol. 77, Studies on the Texts of the Desert of Judah. Leiden: Brill.

Uspensky, Boris. 1983. A Poetics of Composition. The Structure of the Artistic Text and Typology of a Compositional Form. Berkeley: University of California.

van Wolde, Ellen. 1989. “Trendy Intertextuality?” In Intertextuality in Biblical Writings. Essays in Honour of Bas van Iersel, edited by Sipke Draisma and Bastiaan M. F. van Iersel, 43-49. Kampen: Kok.

Vorster, Willem S. 1989. "Intertextuality and Redaktionsgeschichte." In Intertextuality in Biblical Writings. Essays in Honour of Bas van Iersel, edited by Sipke Draisma and Bastiaan M. F. van Iersel, 15-26. Kampen: Kok. 